\title{
Vertical Attenuation Coefficient of Downward Irradiance in Lake Oze
}

\author{
Akira Sugawa
}

\begin{abstract}
In Lake Oze, the downward irradiance in the region $400 \sim 700 \mathrm{~nm} E_{d}$ was measured in 1987. $E_{d}$ was measured at depths $z=0,0.1,0.3,0.5,1 \mathrm{~m}$, and then at $1-\mathrm{m}$ intervals to $8 \mathrm{~m} . E_{d}$ at $z=0 \mathrm{~m}$ was measured just below the lake surface. When the ratio of $E_{d}$ to $E_{d 0}$, which is the value of $E_{d}$ at $z=0 \mathrm{~m}$, is plotted with a logarithmic scale, relation between $E_{d} / E_{d 0}$ and $z$ was approximately linear. The vertical attenuation coefficient of downward irradiance $K_{d}$ ranged from 0.49 to $0.85 \mathrm{~m}^{-1}$.

In Lake Oze, absorption coefficient of the lake water was minimum at wave length $\lambda=570$ or $580 \mathrm{~nm}$, so $E_{d}$ was estimated to be maximum at $\lambda=570$ or $580 \mathrm{~nm}$, and the incident direct solar radiation at $\lambda=570$ or $580 \mathrm{~nm}$ must reach a considerable depth. If it is assumed that the incident direct solar irradiance is mainly attenuated by absorption of the lake water, $K_{d}$ depends on solar altitude and absorption coefficient. When the values of the angle of refraction and absorption coefficient at $\lambda=570 \mathrm{~nm}$ are given, $K_{d}$ for downward irradiance at $\lambda=570 \mathrm{~nm}$ is calculated. The calculated values of $K_{d}$ were in approximate agreement with those obtained from the measurement of $E_{d}$ except in September.
\end{abstract}

Key words : incident direct solar irradiance, downward irradiance, solar altitude, absorption coefficient.

\section{Introduction}

Downward irradiances in lake waters were measured by KIRK $(1977,1981)$, Sugawa (1978), Arai (1981), Weidemann and Bannister (1986), and vertical distributions of downward irradiances were obtained. Downward spectral irradiances in lake and sea waters were measured by Sмiтн et al. (1973), JeRLov (1976), Tsuda (1980), Kishino et.al. (1984), Weidemann and BANNISTER (1986), and spectral distributions of downward irradiances were obtained at different depths.

Lake Oze stretches over Gunma and Fukushima Prefectures. The Ohe River, Hinoki and Wase Creeks, and other smaller creeks flow into the lake, from which the water flows out through the intake. Downward irradiance in Lake Oze was measured monthly during the period from June to October 1987 except July. The location of the observation station is shown by an open circle in Figure 1. Vertical distribution of the ratio of downward irradiance to that just below the lake surface in each month was not equal as in Figure 2. Therefore vertical attenuation coefficient of downward irradiance $K_{d}$ was also not constant. In the present study the author discusses the factors by which $K_{d}$ is influenced.

\section{Measurement of downward irradiance}

Downward irradiance $E_{d}$ was measured with LI-COR LI-192SB underwater quantum sensor for the total quantum flux in the region 400 $\sim 700 \mathrm{~nm}$. All measurements were carried out under sunny condition. The sensor surface was arranged horizontally and the sensor was lowered into the lake water. 


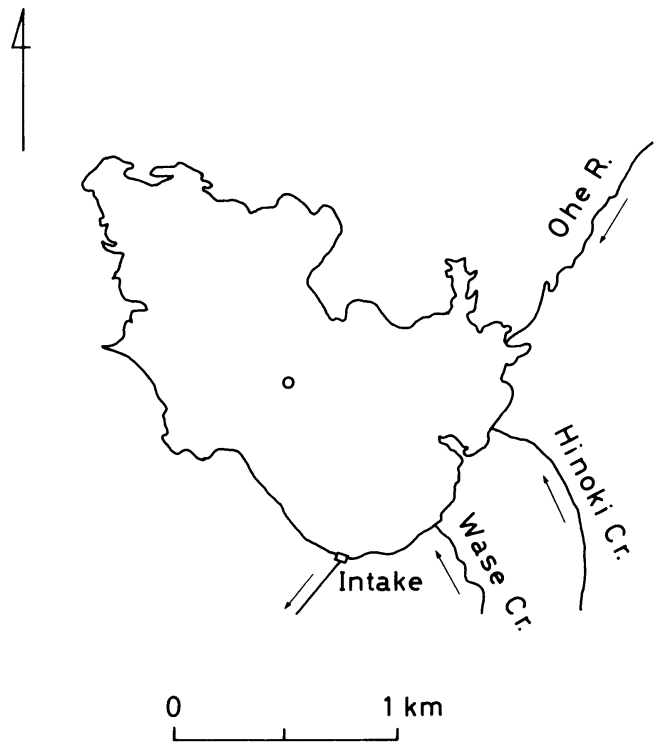

Fig. 1. Lake Oze and location of observation station.

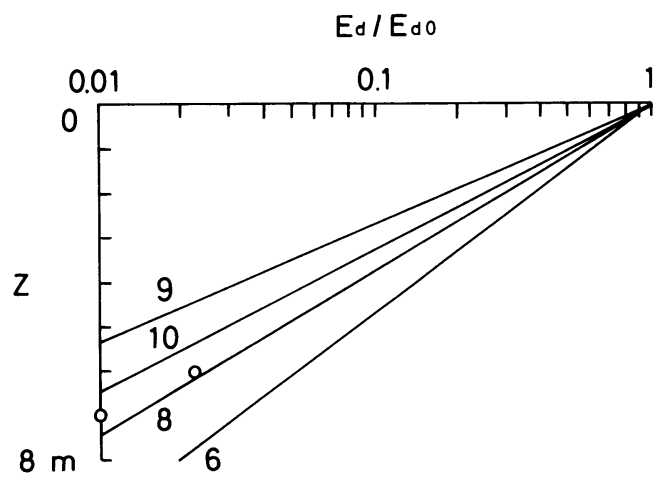

Fig. 2. Vertical distribution of $E_{d} / E_{d 0}$.

Let $z$ be the depth from the lake surface. $E_{d}$ was measured at $z=0,0.1,0.3,0.5,1 \mathrm{~m}$, and then at 1-m intervals to $8 \mathrm{~m}$. $E_{d}$ at $z=0 \mathrm{~m}$ was measured just below the lake surface. Depth of the lake bottom varied from 8.0 to $8.3 \mathrm{~m}$ during the period from June to October.

Let $E_{d 0}$ be the value of $E_{d}$ at $z=0 \mathrm{~m}$. Value of $E_{d 0}$ and measured time are presented in Table 1. When the ratio of $E_{d}$ to $E_{d 0}$ is plotted with a logarithmic scale, the vertical distribution of $E_{d} / E_{d 0}$ was approximately expressed by a straight line as in Figure 2. Numerals on the straight lines represent measured months.

Vertical attenuation coefficient of downward irradiance $K_{d}$ is given by

$$
K_{d}=-\frac{d\left(\ln E_{d}\right)}{d z}
$$

From Figure 2 and Eq. (2-1), $K_{d}$ is obtained and presented in Table 1 . The values of $K_{d}$ ranged from 0.49 to $0.85 \mathrm{~m}^{-1}$.

KIRK (1980) obtained values of $K_{d}$ in lakes in Australia. The values of $K_{d}$ in Lakes Burley Griffin, Ginninderra, George, and Burrinjuck and Corin Dams were 0.91 6.93, 0.84 1.99, 6 . $03, \quad 0.71 \sim 0.90$, and $0.87 \mathrm{~m}^{-1}$, respectively. WeIDEMANN and Bannister (1986) also obtained values of $K_{d}$ in lakes. The values of $K_{d}$ in Irondequoit Bay, which is a lake discharging into Lake Ontario through a narrow and shallow outlet, and of Lakes Onondaga, Otisco, and Oneida, were $0.90 \sim 1.30,1.22,0.64$, and $0.96 \mathrm{~m}^{-1}$, respectively. The value of $K_{d}$ in Lake Oze was nearly equal to that in Lake Otisco but smaller than in the other lakes.

\section{Solar altitude at measured time}

Solar altitude $h$ was given by WADACHI (1979) as

$\sin h=\sin \varphi \sin \delta+\cos \varphi \cos \delta \cos t$

where $\varphi, \delta$, and $t$ are latitude, declination and hour angle.

The value of $\varphi$ at the observation station is about $36^{\circ} 55^{\prime}$, and $\delta$ and $t$ are obtained from

Table 1. Values of $E_{d 0}, K_{d}$, and $h$.

\begin{tabular}{lrccc}
\hline $\begin{array}{l}\text { Date } \\
(1987)\end{array}$ & Time & $\begin{array}{c}E_{d 0} \\
\left(10^{3} \mu \mathrm{E} \cdot \mathrm{m}^{-2} \cdot \mathrm{sec}^{-1}\right)\end{array}$ & $\begin{array}{c}K_{d} \\
\left(\mathrm{~m}^{-1}\right)\end{array}$ & $\begin{array}{c}h \\
\left({ }^{\circ}\right)\end{array}$ \\
\hline 22 June & $14: 50$ & 1.60 & 0.49 & 47.9 \\
24 August & $15: 00$ & 1.39 & 0.66 & 39.2 \\
29 September & $8: 40$ & 1.00 & 0.85 & 31.2 \\
13 October & $9: 22$ & 1.25 & 0.72 & 36.8 \\
\hline
\end{tabular}


measured date and time. When values of $\delta$ and $t$ are given, $h$ is calculated from Eq. (3-1) and presented in Table 1 . The values of $h$ ranged from 31.2 to $47.9^{\circ}$.

\section{Spectral absorption coefficient of lake water}

Spectral absorption coefficient of lake water $a_{y}(\lambda)$ is expressed by

$$
a(\lambda)=a_{y}(\lambda)+a_{p}(\lambda)+a_{w}(\lambda)
$$

where $a_{y}(\lambda), a_{p}(\lambda)$, and $a_{w}(\lambda)$ are absorption coefficients at wave length $\lambda$ by dissolved yellow substance, particulate matter, and pure water, respectively. Water samples were collected from $z=0,3$, and $6 \mathrm{~m}$ at the observation station. Spectral transmittance with reference to distilled water $T(\lambda)$ was measured in the region $400 \sim 700 \mathrm{~nm}$ at $10-\mathrm{nm}$ intervals by Hitachi U-3400 spectrophotometer. $a(\lambda)$ of the water sample was obtained by the following method.

Absorption by dissolved yellow substance : When the water sample is filtered through pore size $0.2 \mu \mathrm{m}$ membrane filter, particulate matter in the water sample is removed, and attenuation of the beam passing through the filtered water with reference to distilled water is due to absorption by dissolved yellow substance. Then $a_{y}(\lambda)$ is expressed by

$$
a_{y}(\lambda)=\frac{1-T(\lambda)}{l}
$$

where $l$ is path length of glass cells, and $10 \mathrm{~cm}$ path length glass cells were used. Values of $a_{y}$ $(\lambda)$ at $50-n m$ intervals are presented in Table 2.

The value of $a_{y}(\lambda)$ increased as the value of $\lambda$ decreased. The values of $a_{y}(\lambda)$ in June and October increased with depth, while those at $z=3 \mathrm{~m}$ in August and September were larger than at $z=0$ and $6 \mathrm{~m}$.

Absorption by particulate matter: When the water sample is not filtered, part of the beam passing through the water sample is scattered. KIRK (1980) showed that the backward scattering coefficient was much smaller than the total scattering coefficient. Then backward scattering may be negligible in comparison with total scattering, and directly transmitted and for- ward scattered beams are measured by attaching Hitachi $150 \mathrm{~mm} \phi$ integrating sphere to Hitachi U-3400 spectrophotometer. When the integrating sphere is used, attenuation of the beam passing through the water sample with reference to distilled water is due to absorption by dissolved yellow substance and particulate matter. Then $a_{y}(\lambda)+a_{p}(\lambda)$ is expressed by

$$
a_{y}(\lambda)+a_{p}(\lambda)=\frac{1-T(\lambda)}{l}
$$

and $5 \mathrm{~cm}$ path length glass cells were used. Therefore $a_{p}(\lambda)$ is obtained by subtracting $a_{y}$ ( $\lambda$ ) from $a_{y}(\lambda)+a_{p}(\lambda)$. Values of $a_{p}(\lambda)$ at 50 -nm intervals are presented in Table 2.

The value of $a_{p}(\lambda)$ increased as the value of $\lambda$ decreased. The value of $a_{p}(\lambda)$ at $z=3 \mathrm{~m}$ in June was larger than at $z=0$ and $6 \mathrm{~m}$, and that at $z=6 \mathrm{~m}$ in August was much larger than at $z=0$ or $3 \mathrm{~m}$. The values of $a_{p}(\lambda)$ at each depth in September and October were nearly equal.

Absorption by pure water : $a_{w}(\lambda)$ was obtained by SMith and BAKer (1981). Values of $a_{w}(\lambda)$ at $50-\mathrm{nm}$ intervals are also presented in Table 2 .

Total absorption by lake water : $a(\lambda)$ is obtained from Eq. (4-1), and vertical distributions of $a(\lambda)$ at 50-nm intervals are presented in Figure 3. Numerals on the lines represent measured months. The values of $a(\lambda)$ at $z=3$ $m$ in June and September were larger than at $z=0$ or $6 \mathrm{~m}$, while that at $z=3 \mathrm{~m}$ in October was smaller than at $z=0$ or $6 \mathrm{~m}$. The value of $a(\lambda)$ at $z=6 \mathrm{~m}$ in August was much larger than at $z=0$ or $3 \mathrm{~m}$. Then the measured values of $E_{d} / E_{d 0}$ at depths deeper than $6 \mathrm{~m}$ were shown by open circles in Figure 2, and smaller than the values shown by the straight line. In the same way, vertical distributions of $a(\lambda)$ at $\lambda=570$ and $580 \mathrm{~nm}$ were obtained. Figure 4 shows the vertical distributions of $a(\lambda)$ at $\lambda=570$ and 580 $\mathrm{nm}$, and the value of $a(\lambda)$ at $\lambda=570$ or $580 \mathrm{~nm}$ became minimum in the region $400 \sim 700 \mathrm{~nm}$.

Kishino et al. (1984) measured $a(\lambda)$ and spectral downward irradiance $E_{d}(\lambda)$ in Lakes Kizaki and Fukamiike, and Shimoda Nabeta Bay. Let $\lambda_{\min }$ and $\lambda_{\max }$ be wave lengths at which $a(\lambda)$ is minimum and $E_{d}(\lambda)$ is maximum. The values of $\lambda_{\min }$ and $\lambda_{\max }$ in Lake 
Table 2. Values of $a_{y}(\lambda), a_{p}(\lambda)$, and $a_{w}(\lambda)$ at 50 -nm intervals.

\begin{tabular}{|c|c|c|c|c|c|c|c|}
\hline \multirow[b]{3}{*}{$\begin{array}{c}\lambda \\
(\mathrm{nm})\end{array}$} & \multicolumn{7}{|c|}{22 June } \\
\hline & \multicolumn{3}{|c|}{$z=0 \mathrm{~m}$} & \multicolumn{2}{|c|}{$z=3 \mathrm{~m}$} & \multicolumn{2}{|c|}{$z=6 \mathrm{~m}$} \\
\hline & $\begin{array}{l}a_{y}(\lambda) \\
\left(\mathrm{m}^{-1}\right)\end{array}$ & $\begin{array}{l}a_{p}(\lambda) \\
\left(\mathrm{m}^{-1}\right)\end{array}$ & $\begin{array}{l}a_{w}(\lambda) \\
\left(\mathrm{m}^{-1}\right)\end{array}$ & $\begin{array}{l}a_{y}(\lambda) \\
\left(\mathrm{m}^{-1}\right)\end{array}$ & $\begin{array}{l}a_{p}(\lambda) \\
\left(\mathrm{m}^{-1}\right)\end{array}$ & $\begin{array}{l}a_{y}(\lambda) \\
\left(\mathrm{m}^{-1}\right)\end{array}$ & $\begin{array}{l}a_{p}(\lambda) \\
\left(\mathrm{m}^{-1}\right)\end{array}$ \\
\hline 400 & 0.66 & 0.85 & 0.02 & 0.75 & 1.01 & 0.93 & 0.77 \\
\hline 450 & 0.31 & 0.57 & 0.02 & 0.39 & 0.70 & 0.53 & 0.52 \\
\hline 500 & 0.14 & 0.40 & 0.03 & 0.20 & 0.53 & 0.34 & 0.39 \\
\hline 550 & 0.07 & 0.30 & 0.06 & 0.12 & 0.39 & 0.24 & 0.26 \\
\hline 600 & 0.02 & 0.22 & 0.24 & 0.08 & 0.33 & 0.18 & 0.18 \\
\hline 650 & 0.01 & 0.21 & 0.35 & 0.07 & 0.27 & 0.13 & 0.20 \\
\hline 700 & 0 & 0.16 & 0.65 & 0.04 & 0.29 & 0.11 & 0.17 \\
\hline \multicolumn{8}{|c|}{24 August } \\
\hline 400 & 0.65 & 0.94 & & 0.77 & 1.13 & 0.57 & 2.28 \\
\hline 450 & 0.25 & 0.68 & & 0.31 & 0.86 & 0.21 & 1.63 \\
\hline 500 & 0.08 & 0.50 & & 0.11 & 0.67 & 0.07 & 1.25 \\
\hline 550 & 0 & 0.38 & & 0.02 & 0.54 & 0 & 0.95 \\
\hline 600 & 0 & 0.30 & & 0 & 0.45 & 0 & 0.72 \\
\hline 650 & 0 & 0.24 & & 0 & 0.40 & 0 & 0.66 \\
\hline 700 & 0 & 0.19 & & 0 & 0.39 & 0 & 0.55 \\
\hline \multicolumn{8}{|c|}{29 September } \\
\hline 400 & 0.45 & 1.87 & & 0.58 & 1.83 & 0.53 & 1.82 \\
\hline 450 & 0.18 & 1.45 & & 0.26 & 1.44 & 0.23 & 1.42 \\
\hline 500 & 0.06 & 1.19 & & 0.12 & 1.22 & 0.10 & 1.16 \\
\hline 550 & 0.02 & 0.96 & & 0.07 & 0.95 & 0.05 & 0.94 \\
\hline 600 & 0 & 0.80 & & 0.04 & 0.79 & 0.02 & 0.76 \\
\hline 650 & 0 & 0.69 & & 0.03 & 0.71 & 0.02 & 0.69 \\
\hline 700 & 0 & 0.63 & & 0.02 & 0.66 & 0.01 & 0.60 \\
\hline \multicolumn{8}{|c|}{13 October } \\
\hline 400 & 0.30 & 1.71 & & 0.38 & 1.61 & 0.52 & 1.63 \\
\hline 450 & 0.10 & 1.24 & & 0.15 & 1.16 & 0.26 & 1.19 \\
\hline 500 & 0.01 & 0.99 & & 0.05 & 0.93 & 0.13 & 0.94 \\
\hline 550 & 0 & 0.73 & & 0 & 0.71 & 0.07 & 0.73 \\
\hline 600 & 0 & 0.61 & & 0 & 0.58 & 0.04 & 0.60 \\
\hline 650 & 0 & 0.53 & & 0 & 0.51 & 0.02 & 0.55 \\
\hline 700 & 0 & 0.49 & & 0 & 0.48 & 0.02 & 0.51 \\
\hline
\end{tabular}

Kizaki were $570 \sim 580$ and $570 \mathrm{~nm}$, as were those in Lake Fukamiike. The value of $\lambda_{\max }$ in Nabeta Bay was $488 \sim 540 \mathrm{~nm}$, and the value of $\lambda_{\min }$ was nearly equal to the value of $\lambda_{\max }$. WEIDEMANN and BANNISTER (1986) also measured $a(\lambda)$ and $E_{d}(\lambda)$ in Irondequoit Bay. The values of $\lambda_{\min }$ and $\lambda_{\max }$ were about 570 and 575 $\sim 580 \mathrm{~nm}$. Therefore it will be seen that the values of $\lambda_{\min }$ and $\lambda_{\max }$ are nearly equal.

In Lake Oze, the value of $\lambda_{\min }$ was 570 or 580 $\mathrm{nm}$, so the value of $\lambda_{\max }$ may be 570 or $580 \mathrm{~nm}$.

\section{Discussion}

JERLOv and NygARD (1969) showed that the value of $K_{d}$ decreases as solar altitude increases because path length of refracted beam to underwater quantum sensor decreases as solar altitude increases. In the measurement in Lake Burley Griffin on 19 November 1975, KIRK (1977) obtained the values of $K_{d}$ as 2.83 $\mathrm{m}^{-1}$ at $h=33^{\circ}$ and $2.51 \mathrm{~m}^{-1}$ at $h=76^{\circ}$. As in Table 1, the relation between $K_{d}$ and $h$ was also 
a

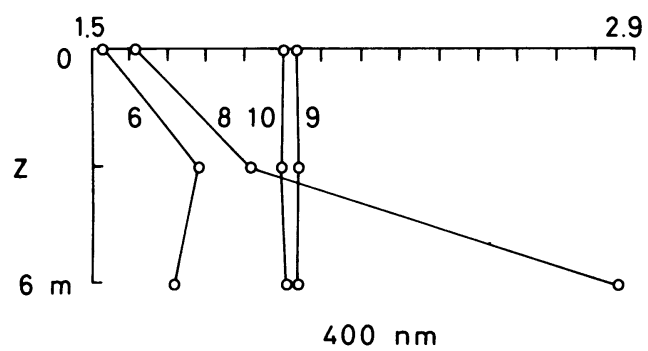

a

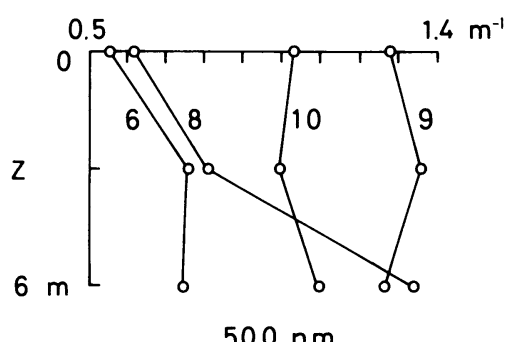

a

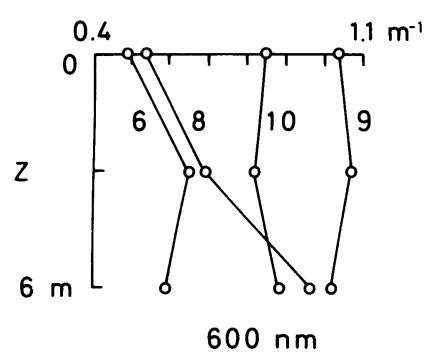

a

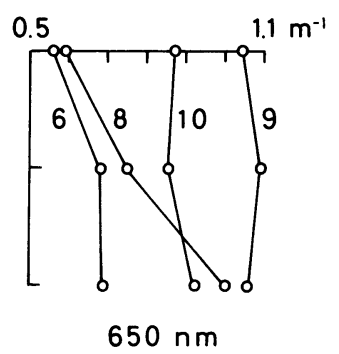

a

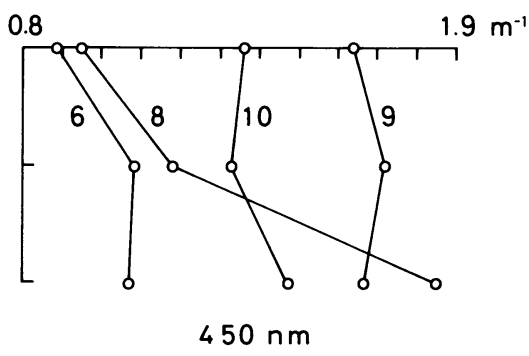

a

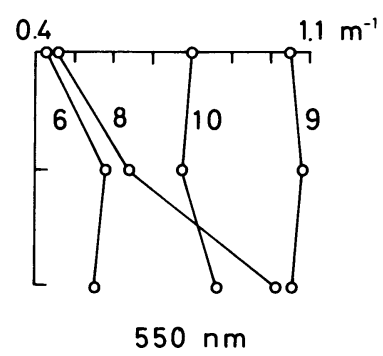

Fig. 3. Vertical distributions of $a(\lambda)$ at $50-\mathrm{nm}$ intervals.

$a$

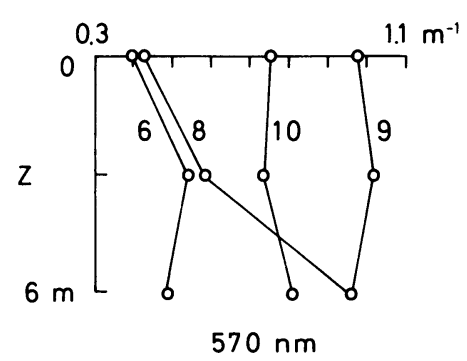

a

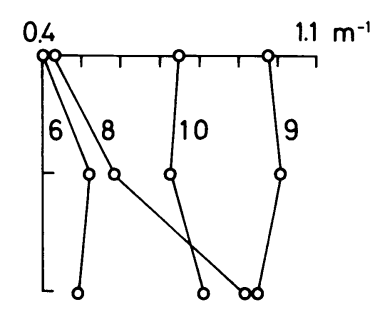

$580 \mathrm{~nm}$

a

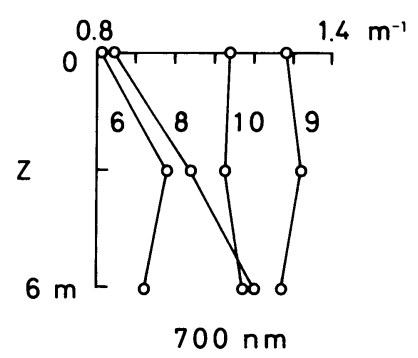

$700 \mathrm{~nm}$ 
applied in Lake Oze.

When incident direct solar radiation is refracted at lake surface and proceeds into lake water, since the refractive index of water relative to air is 1.333, the angle of incidence $i$ and the angle of refraction $j$ are given by

$$
i=90-h
$$

and

$$
j=\sin ^{-1}\left(\frac{\sin i}{1.333}\right)
$$

Values of $i$ and $j$ at measured date and time are presented in Table 3.

Let $E_{0}, E_{1}$, and $E_{2}$ be incident direct solar irradiances on perpendicular planes to the beam at $z=0, z_{1}$, and $z_{2}$, and let $a$ be absorption coefficient of lake water. If incident direct solar irradiance is mainly attenuated by absorption of lake water and $a$ at each depth is constant, $E_{1}$ and $E_{2}$ are given by

$$
E_{1}=E_{0} e^{-a z_{1} \sec j}
$$

and

$$
E_{2}=E_{0} e^{-a z_{2} \sec j}
$$

Let $E_{d 1}$ and $E_{d 2}$ be values of $E_{d}$ at $z=z_{1}$ and $z_{2}$. $E_{d 1}$ and $E_{d 2}$ are given by

$$
E_{d 1}=E_{0} \cos j e^{-a z_{1} \sec j}
$$

and

$$
E_{d 2}=E_{0} \cos j e^{-a z_{2} \sec j}
$$

Therefore $E_{d 1} / E_{d 2}$ becomes

$$
\frac{E_{d 1}}{E_{d 2}}=e^{a\left(z_{2}-z_{1}\right) \sec j}
$$

When $z_{2}-z_{1}$ is substituted for $d z$ in Eq. (2-1), Eq. (2-1) becomes

$$
K_{d}=\frac{\ln \left(E_{d 1} / E_{d 2}\right)}{z_{2}-z_{1}}
$$

Then, using Eq. (5-7), Eq. (5-8) becomes

$$
K_{d}=a \sec j
$$

Since the value of $\lambda_{\max }$ in Lake Oze was estimated as 570 or $580 \mathrm{~nm}$, the incident direct solar radiation at $\lambda=570$ or $580 \mathrm{~nm}$ must reach a considerable depth. The author calculated the value of $K_{d}$ for downward irradiance at $\lambda=$ 570 or $580 \mathrm{~nm}$, and compared with that obtained from Figure 2.

Let $a(570)$ and $a(580)$ be values of $a(\lambda)$ at $\lambda=570$ and $580 \mathrm{~nm}$, and let $a(570)_{m}$ and $a$ $(580)_{m}$ be mean values of $a(570)$ and $a(580)$ at $z=0,3$, and $6 \mathrm{~m}$, except that at $z=6 \mathrm{~m}$, which was much larger than at $z=0$ and $3 \mathrm{~m}$ in August. In Lake Oze, the value of $a(570)_{m}$ was equal to $a(580)_{m}$ and is presented in Table 3. When values of $j$ and $a(570)_{m}$ are given, $K_{d}$ for downward irradiance at $\lambda=570 \mathrm{~nm}$ is calculated from Eq. (5-9) and presented in Table 3. As in Tables 1 and 3, the calculated values of $K_{d}$ were in approximate agreement with those obtained from Figure 2 except that in Septem. ber.

\section{Acknowledgements}

The author wishes to express his thanks to Dr. A. UJIIE and the staff of Gunma Institute of Public Health, and Mr. M. Inagawa of Gunma University for their assistance in the field measurements.

\section{摘要}

\section{尾瀬沼内の下向きの太陽放射量の垂直隇衰係数}

1987 年の 6 月から 10 月まで, 7 月を除き月一回, 尾瀬沼において 400〜700 nm の範囲の下向きの太 陽放射量 $E_{d}$ を測定した。測定は深度 $0,0.1,0.3$, $0.5,1 \mathrm{~m}, 1 \mathrm{~m}$ 以深は $1 \mathrm{~m}$ 間隔で $8 \mathrm{~m}$ まで行なっ

Table 3. Values of $i, j, a(570)_{m}$, and $K_{d}$.

\begin{tabular}{lrcccc}
\hline $\begin{array}{l}\text { Date } \\
(1987)\end{array}$ & Time & $\begin{array}{c}i \\
\left({ }^{\circ}\right)\end{array}$ & $\begin{array}{c}j \\
\left({ }^{\circ}\right)\end{array}$ & $\begin{array}{c}a(570)_{m} \\
\left(\mathrm{~m}^{-1}\right)\end{array}$ & $\begin{array}{c}K_{d} \\
\left(\mathrm{~m}^{-1}\right)\end{array}$ \\
\hline 22 June & $14: 50$ & 42.1 & 30.2 & 0.47 & 0.54 \\
24 August & $15: 00$ & 50.8 & 35.5 & 0.50 & 0.61 \\
29 September & $8: 40$ & 58.8 & 39.9 & 0.98 & 1.28 \\
13 October & $9: 22$ & 53.2 & 36.9 & 0.76 & 0.95 \\
\hline
\end{tabular}


た。深度 $0 \mathrm{~m}$ の值は水面直下の值である。 深度 $0 \mathrm{~m}$ の下向きの太陽放射量を $E_{d 0}$ とし, $E_{d} /$ $E_{d 0}$ の值を対数目盛で表わすと, $E_{d} / E_{d 0}$ と深度との 関係は Figure 2 のごとくほぼ直線で表わされた。 Figure 2 から垂直減衰係数を求めると，その值は $0.49 \sim 0.85 \mathrm{~m}^{-1}$ の範囲内であった。

尾瀬沼の湖水の吸収係数は, 波長が 570 または $580 \mathrm{~nm}$ において最小であった。したがって下向き の太陽放射量は波長 570 または $580 \mathrm{~nm}$ において最 大と考えられる。

湖水内に入射した太陽放射の減衰が，主に湖水 の吸収によるものと考えるならば, 波長 $570 \mathrm{~nm}$ の 下向きの太陽放射量の垂直減衰係数は，太陽高度 と波長 $570 \mathrm{~nm}$ の湖水の吸収係数から計算すること ができる。計算された垂直減衰係数は，9月を除 くと Figure 2 から求められた値とほほ等しくな ることがわかった。

\section{References}

ARAI, T. (1981) : Attenuation of incident solar radiation in lake water. Jpn. J. Limnol., 42 : 9299.

Jerov, N. G. and K. NyGÅRD (1969) : Influence of solar elevation on attenuation of underwater irradiance. Univ. Copenhagen, Inst. Phys. Oceanogr. Rep., $4: 9$.

Jerlov, N. G. (1976) : Marine Optics. Elsevier.

KIRK, J. T. O. (1977) : Use of a quanta meter to measure attenuation and underwater reflectance of photosynthetically active radiation in some inland and coastal south eastern Australian waters. Aust. J. Mar. Freshwater Res., $28: 9-21$.

KIRK, J. T. O. (1980) : Relationship between nephelometric turbidity and scattering coeffi- cients in certain Australian waters. Aust. J. Mar. Freshwater Res., 31:1-12.

KIRK, J. T. O. (1981) : Estimation of the scattering coefficient of natural waters using underwater irradiance measurements. Aust. J. Mar. Freshwater Res., 32 : 533-539.

Kishino, M., C. R. Booth and N. Okami (1984) : Underwater radiant energy absorbed by phytoplankton, detritus, dissolved organic matter, and pure water. Limnol. Oceanogr., $29: 340^{-}$ 349.

Smith, R. C., J. E. Tyler and C. R. Goldman (1973) : Optical properties and color of Lake Tahoe and Crater Lake. Limnol. Oceanogr., 18 : 189199.

Smith, R. C. and K. S. BAKer (1981) : Optical properties of the clearest natural waters $(200-$ $800 \mathrm{~nm})$. Appl. Opt., $20: 177-184$.

SugAwA, A. (1978) : On the attenuation of the solar downward irradiance in waters. Sci. Rep. Fac. Educ. Gunma Univ., 27 : 37-49.

TsudA, R. (1980) : Measurements of underwater spectral irradiance in Lake Biwa. Jpn. J. Limnol., 41 : 57-67.

WADACHI, K. (ed.) (1979) : Encyclopedia of meteorology (in Japanese). Tokyodo-shuppan.

Weidemann, A. D. and T. T. BAnnister (1986) : Absorption and scattering coefficients in Irondequoit Bay. Limnol. Oceanogr., 31 : 567-583.

(著者: 須川 明, 群馬大学教育学部, $テ 371$ 前橋市 荒牧町 4 丁目 2 番地: Akira SugAWA, Faculty of Education, Gunma University, 4-2 Aramaki-cho, Maebashi 371)

Received : 14 March 1988

Accepted : 13 October 1988 